\title{
Occurrence of Trichograma Parasitoids in Eggs of Soybean Lepidopteran Pests in Mato Grosso, Brazil
}

\author{
Angélica Massaroli ${ }^{1}$, Alessandra Regina Butnariu ${ }^{1} \&$ Augusta Karkow Doetzer ${ }^{1}$ \\ ${ }^{1}$ Department of Biological Sciences, University of Mato Grosso State, Brazil \\ Correspondence: Augusta Karkow Doetzer, Rodovia MT 358, Km 07, Jardim Aeroporto, Tangará da Serra, MT, \\ CEP: 78300-000, Brazil. E-mail: alebut@unemat.com; gutaunemat@gmail.com
}

Received: January 14, 2014 Accepted: February 18, 2014 Online Published: March 5, 2014

doi:10.5539/ijb.v6n2p97

URL: http://dx.doi.org/10.5539/ijb.v6n2p97

\begin{abstract}
Occurrence of parasitoids in eggs of soybean lepidopteran pests, such as velvetbean caterpillar, soybean loopers and others the genus Spodoptera and Helicoverpa in Mato Grosso, Brazil was studied. Due to the scarcity of information on the natural occurrence of parasitoids in lepidopteran eggs in soybean fields in Mato Grosso surveys were conducted in Tangará da Serra to verify the occurrence these parasitoids. Surveys were conducted in two areas in Tangará da Serra, with a total of 591 eggs, of which 138 and 77 eggs were collected in area I and 274 and 102 eggs in area II, during the 2008/2009 and 2009/2010 soybean seasons, respectively. From the eggs collected in area I, $26.6 \%$ were parasitized in the first year and $30.0 \%$ in the second season. In area II, the parasitism rates were $40.2 \%$ and $27.5 \%$ for the first and second season respectively. The species of parasitoid collected was Trichogramma pretiosum Riley, 1879 (Hymenoptera: Trichogrammatidae) totaling 354 parasitoids. We conclude that there is a natural occurrence of T. pretiosum, this being the species of egg parasitoid found, and that parasitism rates were higher when compared with other studies under natural conditions, especially considering the large number of chemical products used in the fields. The identification of the eggs parasitoids in Mato Grosso State is important to development of biological control programs for lepidopteran pests.
\end{abstract}

Keywords: insecta, natural enemies, Noctuidae, biocontrol, pesticides, Brazil

\section{Introdution}

Brazil is a major producer of soybeans (Glycine $\max$ L.), and the state of Mato Grosso is the major producer of this grain, with a planted area of 6.16 million hectares, accounting for $27.5 \%$ of the national production (CONAB, 2010). However, the large size of the area occupied by soybeans favors the incidence of insect pests in the crop (Corrêa-Ferreira \& Panizzi, 1980). Among the pests that attack soybeans defoliating caterpillars, such as velvetbean caterpillar, soybean loopers and others the genus Spodoptera and Helicoverpa stand out for decreasing leaf area, and consequently lowering the photosynthetic rate which decreases productivity, while leaving the plant susceptible to disease and sometimes causing its death. In most cases these pests are controlled with wide spectrum chemicals that reduce the action of natural enemies. However, the pests eventually become resistant, while the chemicals pose health hazards and environmental contamination.

For these reasons, states such as Rio Grande do Sul (Costa \& Link, 1974), Paraná (Corrêa-Ferreira et al., 1998; Foerster \& Avanci, 1999), São Paulo (Campos et al., 1997), Mato Grosso do Sul (Godoy et al., 2005), Minas Gerais (Venzon et al., 2000), Distrito Federal (Medeiros et al., 1997) and Acre (Thomazini, 2001) have developed research on species of insect pests and natural enemies, aiming at the implementation of biological control programs.

Among the natural enemies that act in reducing pest populations, egg parasitoids are very effective, since they prevent the development of the pest while still in the egg stage and thus avoid damage to the crop. Egg parasitoids of the genus Trichogramma (Hymenoptera: Trichogrammatidae) are important because they parasitize eggs of Lepidoptera, Hemiptera and Coleoptera that attack various crops (Parra \& Zucchi, 2004) and, for this reason, are used in biological control programs worldwide (Beserra \& Parra, 2004). Currently, there are 190 known species of Trichogramma, and 38 of these occur in South America, 28 of which have been recorded in Brazil (Moreira et al., 2009). Despite the importance of soybean production in the state of Mato Grosso, no research has been carried out in the state regarding the occurrence of egg parasitoids, although their effectiveness has been proven by previous research (Foerster \& Avanci, 1999; Foerster \& Butnariu, 2004). 
Due to the scarcity of information on the natural occurrence of parasitoids in lepidopteran eggs in soybean fields in Mato Grosso, surveys were conducted in two areas in Tangara da Serra with the aim to verify the occurrence of the Trichogramma parasitoids and assess the rates of parasitism. The occurrence of the phytophagous Lepidoptera was also assessed, as well as the pesticides used in the study areas.

\section{Materials and Methods}

\subsection{Study Areas}

The study was conducted in two areas located in the municipality of Tangará da Serra, Mato Grosso, Brazil, cultivated with soybean. The first area (area I) is cultivated with conventional soybean and a dense submontane forest reserve $\left(14^{\circ} 39^{\prime} 53^{\prime \prime} \mathrm{S}\right.$ and $\left.57^{\circ} 24^{\prime} 30^{\prime \prime} \mathrm{W}\right)$. The second area (area II), was planted with organic soybean until the previous year and then conventionally during the sampling season. This area has Cerrado reserves $\left(14^{\circ} 18^{\prime} 44^{\prime \prime} \mathrm{S}\right.$ and $\left.57^{\circ} 45^{\prime} 18^{\prime \prime} \mathrm{W}\right)$ and is located $90 \mathrm{~km}$ away from area I. Temperature and relative humidity (RH) of the areas were obtained using a digital thermohygrometer on the sampling days. The average temperature and RH were $28.6^{\circ} \mathrm{C}$ and $59.8 \%$ in area I and $26.8^{\circ} \mathrm{C}$ and $67.5 \%$ in area II.

\subsection{Sampling of Lepidopteran Eggs}

Eggs of Lepidoptera were collected during the crop seasons of 2008/2009 and 2009/2010 in the months of November, December and January (vegetative period and early reproductive period). Two samplings were performed per month for 1.5 hours each, except for the second crop in the area II, where monthly samples were collected.

The sampling methodology used was described by Foerster and Avanci (1999): soybean leaves containing eggs were collected and taken to the laboratory where the eggs were removed from the leaves with the help of a fine brush under a stereomicroscope and individualized in $1.5 \mathrm{ml}$ microtubes which were kept in conditions controlled of BOD at $25{ }^{\circ} \mathrm{C}$ and $70 \%$ relative humidity.

The occurrence of parasitism was checked daily and the number of emerged parasitoids per host egg and sex of the individuals determined by the morphological characteristics of the antennae (Querino \& Zucchi, 2003). When parasitoids emerged, females were placed in microtubes containing $70 \%$ ethanol and males were used to identify the species.

\subsection{Identification of Parasitoids}

Specimens were identified according to the morphological characters of the male genitalia (Nagaraja \& Nagarkatti, 1973). Parasitoids were cleared in acetic acid for 24 hours, and mounted individually on glass slides in a micro-droplet of Hoyer's medium. Specimens were mounted with their ventral side up and legs pushed to the side, leaving the genitals free for observation. Another micro-droplet was placed on the parasitoid followed by the coverslip. After confirming the sex, the slides were sent for identification to Dr. Ranyse B. Querino of EMBRAPA Meio-Norte.

Identified specimens were deposited in the entomological collection of the laboratory of Zoology at the Centro de Pesquisas, Estudos e Desenvolvimento Agro-ambientais (CPEDA) at the Universidade do Estado de Mato Grosso campus de Tangará da Serra (UNEMAT/CUTS).

\subsection{Sampling of Lepidopteran Larvae}

All larvae found at the sampling points were collected manually in order to record the lepidopteran species found in the area. These were taken to the laboratory for identification using books and field guides. The identification of adults by an expert was not possible, since chemical products that were applied in the areas prevented the collected larvae from reaching the adult stage.

\subsection{Pesticides Used}

Using a predefined form, an interview was conducted with the persons responsible for applying the pesticides in the fields to obtain the names of the products used.

In both areas studied chemical management is the only method of pest control used. The main insecticides used were Lambda-cyhalothrin (Karate Zeon ${ }^{\circledR}$ ), Thiodicarb (Larvin $\left.{ }^{\circledR}\right)$, Thiomethoxam (Engeo Pleno ${ }^{\circledR}$ ), Metal phosphides (Fosfito $\AA$ ), Organophosphates (Metamidofós $\left.{ }^{\circledR}\right)$. The herbicides used were Chlorimuron (Classic ${ }^{\circledR}$ ), Fomesafen (Flex $\left.{ }^{\circledR}\right)$, Fluazifop (Fusilade ${ }^{\circledR}$ ), Glyphosate (Roundup ${ }^{\circledR}$ ), and the fungicides were Azoxystrobin and Cyproconazole (Priori Xtra ${ }^{\circledR}$ ) and Triactol (Alto $100 \circledR$ ). All pesticides used were recommended by agronomists. 


\subsection{Data Analysis}

We calculated the mean percentage of parasitism in the study areas and analyzed the data using a one way analysis of variance $(\mathrm{p} \leq 0.05)$ (ANOVA). The sex ratio was calculated for the parasitoids collected in the 2009/2010 season, using the formula: $\mathrm{rs}=$ №우 / (№우 + №ㅇ $)$. The average number of parasitoids emerged per egg was also calculated.

\section{Results and Discussion}

A total of 591 eggs were collected in the two areas, of which 138 and 77 eggs were collected in area I and 274 and 102 eggs area II, during the 2008/2009 and 2009/2010 soybean seasons, respectively. From the eggs collected in area I, 26.6\% were parasitized in the first year and $30.0 \%$ in the second season. In area II, the parasitism rates were $40.2 \%$ and $27.5 \%$ for the first and second season, respectively (Figure 1 ). The average parasitism in two areas was $35.7 \%$, without significant difference between the two areas $(\mathrm{F}=0.49$ and $\mathrm{P}=0.68$ $(\mathrm{p} \leq 0.05)$.

Despite the fact that the parasitoids were influenced by the host and the chemical management employed in the areas (Zago et al., 2010), percentages of parasitism in Mato Grosso were higher than those in Paraná, where Avanci et al. (2005) found that parasitism in eggs of Anticarsia gemmatalis Hübner, 1818 (Lepidoptera: Noctuidae) varied from $3.7 \%$ to $11.5 \%$ during four seasons.

The species of parasitoid collected was Trichogramma pretiosum Riley, 1879 (Hymenoptera: Trichogrammatidae) totaling 354 parasitoids. According to Gonçalves et al. (2003), this species is the most widely distributed in Brazil and, according to Zucchi and Monteiro (1997), it is the most generalist and is associated with 26 host species (Potrich et al., 2009).

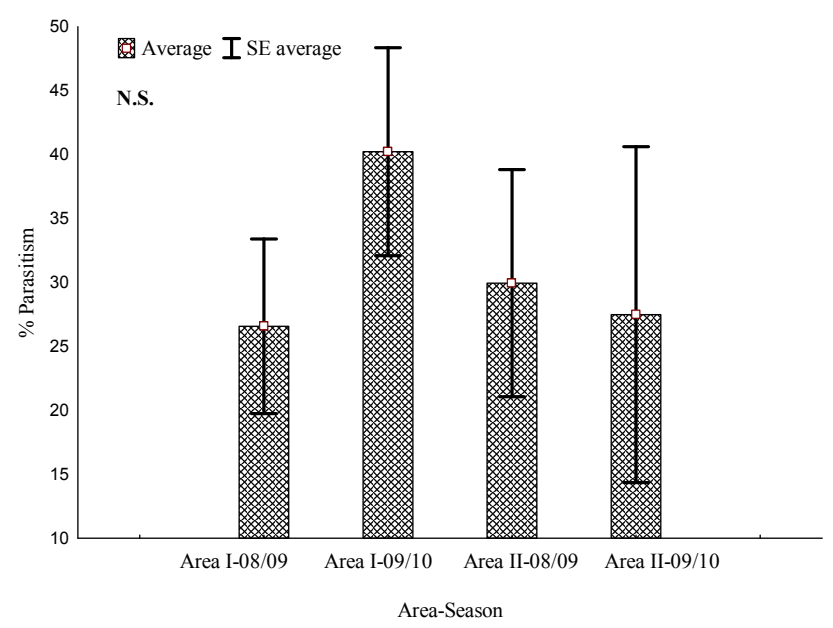

Figure 1. Percentage of eggs of noctuid pests on soybean parasitized by Trichograma pretiosum. The two areas were sampled in Mato Grosso, Brazil during the 2008/2009 and 2009/2010 growing seasons. The rates of parasitism were not significantly different according to ANOVA $(\mathrm{F}=0.49 ; \mathrm{P}=0.68 ; \mathrm{p} \leq 0.05)$

Avanci et al. (2005) also recorded a predominance of T. pretiosum, which accounted for $80 \%$ of the parasitized eggs of A. gemmatalis. In another study in Paraná, during five consecutive soybean seasons Foerster and Avanci, (1999) recorded $90 \%$ of the eggs of $A$. gemmatalis parasitized by T. pretiosum. In maize (Zea mays L.) crops in Minas Gerais, Tironi and Ciociola (1994) recorded more than $90 \%$ of the eggs of Helicoverpa zea (Boddie, 1850) (Lepidoptera: Noctuidae) parasitized by T. pretiosum.

According to Moreira et al. (2009), in Brazil, T. pretiosum is the most frequently occuring parasitoid and is associated with various hosts in different cultures, such as Tuta absoluta (Meyrick, 1917) in tomato (Pratissoli et al., 2005), Spodoptera frugiperda (Smith, 1797) (Bessera \& Parra, 2003) and H. zea (Pratissoli \& Oliveira, 1999) in maize, Plutella xylostella (Linnaeus, 1758) in cabbage (Pereira et al., 2004; Zago et al., 2010), Heliothis virescens (Fabricius, 1781) in cotton (Zucchi et al., 1989), A. gemmatalis and Chrysodeixis (= Pseudoplusia) includens (Walker, 1858) in soybean (Bueno et al., 2009).

Three species of phytophagous Lepidoptera were found in area I, during two seasons, of which $74.9 \%$ was $C$. 
includens, 20.5\% A. gemmatalis and 4.6\% Spodoptera spp. In area II there was an inversion of these data, being 69.4\% Spodoptera spp., 19.2\% A. gemmatalis and $11.4 \%$ C. includens.

This inversion can be related to the type of management used as in area I, where regular insecticide applications were made, since the area has always been planted with conventional soybean. This may have favored the emergence of resistant strains of $C$. includens, justifying the large number of this species. The high number of Spodoptera spp. Can be related to the conventional maize has been cultived after last organic soybean cultivation. Maize cultivastion was not appropriately carried out, leaving residues on the crop.

Considering the presence of larvae, we concluded that the parasitized eggs belong to these species since the identification of eggs is difficult due to the darkening of the egg as the parasitoid develops inside the eggs. Thus, all eggs were included in the count. However, the method of oviposition found in the areas (individual eggs on leaves) which is characteristic of $A$. gemmatalis and $C$. includens, and leads us to infer that these species were predominant when compared to eggs of Spodoptera spp., which are laid in masses of more than 100 eggs.

The sex ratio is an important feature of biological control programs, since the greater the production of females, the greater the number of parasitized eggs and parasitoids in the next generation. In this study, the sex ratio of the parasitoids was $0.5 \pm 0.10$ for eggs collected in area I and $0.6 \pm 0.07$ for eggs collected in area II during the 2009/2010 season. Avanci et al. (2005) obtained similar results in eggs of A. gemmatalis under natural conditions as the ones recorded in the area II $(0.65 \pm 0.02)$ for T. pretiosum. Bueno et al. (2009) observed, under laboratory conditions, similar results in eggs of $C$. includens $(0.70 \pm 0.02)$. Thus we can infer that environmental differences do not affect the sex ratio of the parasitoids.

Of the eggs collected, the average number of adults emerged per egg was (average \pm SE) $1.4 \pm 0.46$ and $1.6 \pm$ 0.36 in I area (area with predominance of larvae of $C$. includens) and $1.6 \pm 0,11$ and $1.3 \pm 0.06$ in II area (where occurrence of $A$. gemmatalis was higher than that of $C$. includens) in the 2008/2009 and 2009/2010 seasons, respectively. Bueno et al. (2009) obtained lower emergence rates for $C$. includens $(1.0 \pm 0.0)$ whereas Avanci et al. (2005) recorded higher emergence of parasitoids in eggs of $A$. gemmatalis $(2.2 \pm 0.06)$.

Differences in the number of adults emerged per egg can be associated with the host species. Nutritional characteristics, egg size, and adaptations of the parasitoid are very important in this process (Bueno et al., 2009).

As explained above, pesticides were utilized during sampling periods, and the use of chemicals also influenced the viability of parasitoids. Bueno et al. (2008) showed a 50\% reduction in the viability of eggs parasitized by $T$. pretiosum in laboratory with the use of products such as Lambda-cyhalothrin and Thiodicarb. Moreover, other products such as glyphosate and chlorimuron reduced by $100 \%$ the viability of parasitized eggs in laboratory tests, and all these products were used in the areas sampled in our study.

Despite the use of these products in the study areas, parasitoids were present throughout the period the collections were made. Figures $2 \mathrm{~A}$ and $2 \mathrm{~B}$ show the percentage of parasitism for each sampling. 

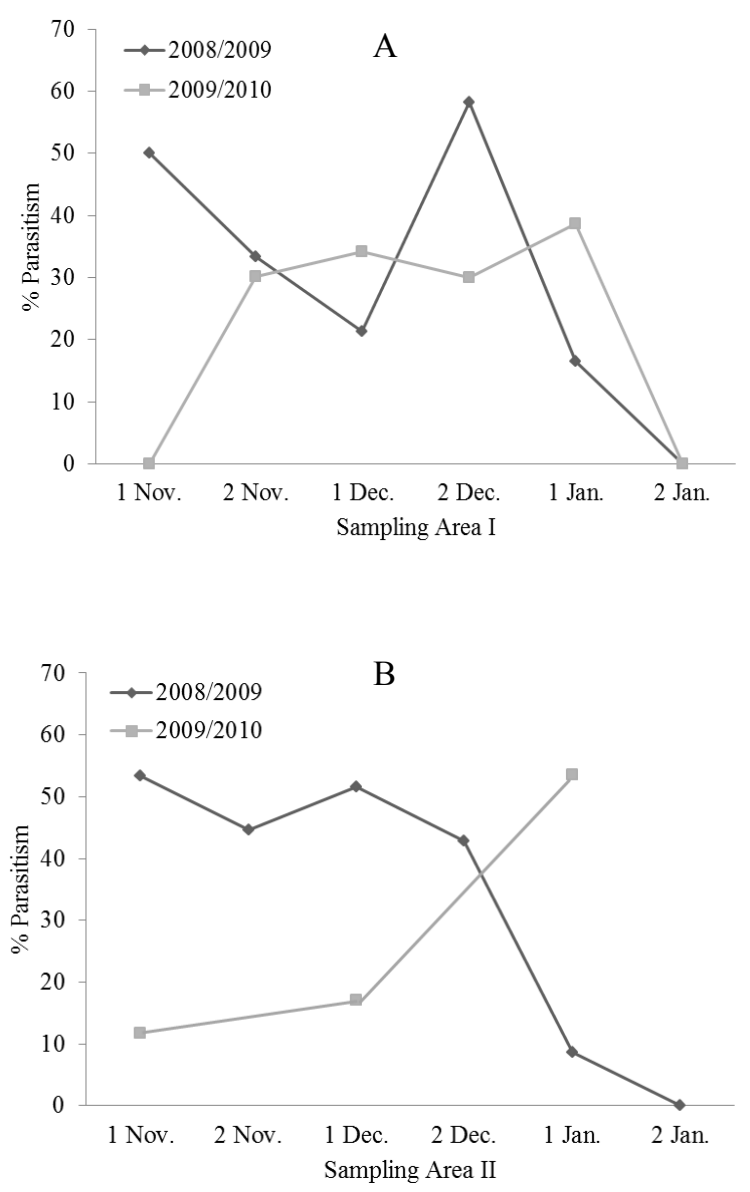

Figure 2. Population fluctuation of Trichogramma pretiosum egg parasitoids during the 2008/2009 and 2009/2010 soybean seasons in the two areas sampled in Mato Grosso, Brazil

During the first year, in area I, the parasitoids were present from the first sampling (Figure 2A), and the level of parasitism was higher when compared to the second season. Declines in the percentage of parasitism, as seen in the samplings made in November (2 Nov.) and December (1 Dec.), may be related to the use of pesticides, increasing mortality of caterpillars and unavailability of eggs.

In area II (Figure 2B), during the first season, since the beginning of tsampling, parasitism remained similar and, in January, when soybeans entered the stage of pre-harvest, there was a decrease in the percentage of parasitism. In the second soybean season, due to difficulties in accessing the area, there were only three samples taken., They showed inverse relation to the first year, which may also be related to the use of chemical products as this was the second year of chemical use in the area.

\section{Conclusions}

Concluded that Trichogramma pretiosum was the only species parasitizing lepidopteran eggs on soybeans in our sampling areas, and that the parasitism rate was higher than recorded in other Brazilian regions. The lepidopteran pests the most abundant lepidopteran species in the areas investigated are Chrysodeixis includes, Anticarsia gemmatalis and Spodoptera sp.

\section{Acknowledgments}

We thank to Dr. Ranyse B. Querino of EMBRAPA Meio-Norte (Teresina-PI), for the identification of parasitoids, to Dr. Luis Amilton Foerster and the entire staff of the Laboratorio de Controle Integrado de Insetos (UFPR) for the suggestions on collection and management of parasitoids. To the producers who allowed us to collect in their areas and to FAPEMAT for the Scientific Initiation scholarship in 2008-2009. 


\section{References}

Avanci, M. R. F., Foerster, L. A., \& Cañete, C. L. (2005). Natural parasitism in eggs of Anticarsia gemmatalis Hübner (Lepidoptera, Noctuidae) by Trichogramma spp. (Hymenoptera, Trichogrammatidae) in Brazil. Revista Brasileira de Entomologia, 49, 148-151. http://dx.doi.org/10.1590/S0085-56262005000100017

Beserra, E. B., \& Parra, J. R. P. (2003). Comportamento de parasitismo de Trichogramma atopovirilia Oatman \& Platner e Trichogramma pretiosum Riley (Hymenoptera, Trichogrammatidae) em posturas de Spodoptera frugiperda (J. E. Smith) (Lepidoptera, Noctuidae). Revista Brasileira de Entomologia, 47, 205-209. http://dx.doi.org/10.1590/S0085-56262003000200009

Beserra, E. B., \& Parra, J. R. P. (2004). Biologia e parasitismo de Trichogramma atopovirilia Oatman \& Platner e Trichogramma pretiosum Riley (Hymenoptera, Trichogrammatidae) em ovos de Spodoptera frugiperda (J.E. Smith) (Lepidoptera, Noctuidae). Revista Brasileira de Entomologia, 48, 119-126. http://dx.doi.org/10.1590/S0085-56262004000100020

Bueno, A. F., Bueno, R. C. O. F., Parra, J. R., \& Vieira, S. S. (2008). Efeitos dos agroquímicos utilizados na cultura da soja ao parasitoide de ovos Trichogramma pretiosum. Ciência Rural, 38, 1495-1503. http://dx.doi.org/10.1590/S0103-84782008000600001

Bueno, R. C. O. F., Parra, J. R. P., Bueno, A. F., \& Haddad, M. L. (2009). Desempenho de tricogramatídeos como potenciais agentes de controle de Pseudoplusia includens Walker (Lepidoptera: Noctuidae). Neotropical Entomology, 38, 389-394. http://dx.doi.org/10.1590/S1519-566X2009000300015

Campos, O. R., Campos, A. R., \& Lara, F. M. (1997). Ocorrência sazonal de insetos pragas e predadores entomófagos em duas variedades de soja. Cultura Agronômica, 6, 1-11.

Companhia Nacional de Abastecimento (CONAB). (2010). Acompanhamento de safra brasileira: grãos, quarto levantamento, janeiro $2010 \quad-\quad$ Brasilia, DF. Retrieved from http://www.conab.gov.br/conabweb/download/safra/3graos_09.12.pdf

Costa, E. C., \& Link, D. (1974). Incidência de percevejos em soja. Revista Centro de Ciências Rurais, 4, $397-400$.

Retrieved

from

http://cascavel.ufsm.br/revista_new/ojs/index.php/RCCCR/article/viewFile/226/226

Corrêa-Ferreira, B. S., Nunes, M. C., \& Uguccioni, L. D. (1998). Ocorrência do parasitoide Hexacladia smithii Ashmead em Adultos de Euschistus heros (F.) no Brasil. Anais da Sociedade Entomológica do Brasil, 27, 495-498.

Corrêa-Ferreira, B. S., \& Panizzi, A. R. (1980). Geometrídeos em soja: Flutuação estacional e ressurgência após o uso de inseticidas. Pesquisa Agropecuária Brasileira, 15, 159-161.

Foerster, L. A., \& Avanci, M. R. F. (1999). Egg parasitoids of Anticarsia gemmatalis Hübner (Lepidoptera: Noctuidae) in soybeans. Anais da Sociedade Entomológica do Brasil, 28, 545-548. http://dx.doi.org/10.1590/S0301-80591999000300025

Foerster, L. A., \& Butnariu, A. R. (2004). Development, reproduction, and longevity of Telenomus cyamophylax, egg parasitoid of the velvetbean caterpillar Anticarsia gemmatalis, in relation to temperature. Biological Control, 29, 1-4. http://dx.doi.org/10.1016/S1049-9644(03)00133-6

Godoy, K. B., Galli, J. C., \& Ávila, C. J. (2005). Parasitismo em ovos de percevejos da soja Euschistus heros (Fabricius) e Piezodorus guildinii (Westwood) (Hemíptera: Pentatomidae) em São Gabriel do Oeste, MS. Ciência Rural, 35, 455-458. Retrieved from http://www.redalyc.org/pdf/331/33135234.pdf

Gonçalves, J, R., Holtz, A. M., Pratissoli, D., \& Guedes, R. N. C. (2003). Avaliação da qualidade de Trichogramma pretiosum (Hymenoptera:Trichogrammatidae) em ovos de Sitotroga cerealella (Lepidoptera: Gelechiidae). Acta Scientiarum Agronomy, 25, 485-489. http://dx.doi.org/10.4025/actasciagron.v25i2.2328

Medeiros, M. A., Schimidt, F. V. G., Loiácono, M. S., Carvalho, V. F., \& Borges, M. (1997). Parasitismo e predação em ovos de Euschistus heros (Fab.) (Heteroptera: Pentatomidae) no Distrito Federal, Brasil. Anais da Sociedade Entomológica do Brasil, 26, 397-401. http://dx.doi.org/10.1590/S0301-80591997000200026

Moreira, M. D., Santos, M. C. F., Beserra, E. B., Torres, J. B., \& Almeida, R. P. (2009). Parasitismo e Superparasitismo de Trichogramma pretiosum Riley (Hymenoptera: Trichogrammatidae) em Ovos de Sitotroga cerealella (Oliver) (Lepidoptera: Gelechiidae). Neotropical Entomology, 38, 237-242. http://dx.doi.org/10.1590/S1519-566X2009000200011 
Nagaraja, H., \& Nagarkatti, S. (1973). A Key to some New World species of Trichogramma (Hymenoptera: Trichogrammatidae), with descriptions of four new species. Proceedings of the Entomological Society of Washington, 85, 710-713.

Parra, J. R. P., \& Zucchi, R. A. (2004). Trichogramma in Brazil: Feasibility of use after twenty years of research. Neotropical Entomology, 33, 271-281.

Pereira, F. F., Barros, R., Pratissoli, D., \& Parra, J. R. P. (2004). Biologia e exigências térmicas de Trichogramma pretiosum Riley e T. exiguum Pinto \& Platner (Hymenoptera: Trichogrammatidae) criados em ovos de Plutella xylostella (Lepidoptera: Plutelidae). Neotropical Entomology, 33, 231-236. http://dx.doi.org/10.1590/S1519-566X2004000200014

Potrich, M., Alves, L. F. A., Haas, J., Silva, E. R. L., Daros, A., Pietrowski, V., \& Neves, P. M. O. J. (2009). Seletividade de Beauveria bassiana e Metarhizium anisopliae a Trichogramma pretiosum Riley (Hymenoptera: Trichogrammatidae). Neotropical Entomology, 38, 822-826. http://dx.doi.org/10.1590/S1519-566X2009000600016

Pratissoli, D., Thuler, R. T., Andrade, G. S., Zanotti, L. C. M., \& Silva, A. F. (2005). Estimativa de Trichogramma pretiosum para o controle de Tuta absoluta em tomateiro estaqueado. Pesquisa Agropecuária Brasileira, 40, 715-718. http://dx.doi.org/10.1590/S0100-204X2005000700013

Pratissoli, D., \& Oliveira, H. N. (1999). Influência da idade dos ovos de Helicoverpa zea (Boddie) no parasitismo de Trichogramma pretiosum Riley. Pesquisa Agropecuária Brasileira, 34, 231-236. http://dx.doi.org/10.1590/S0100-204X1999000500023

Querino, R, B., \& Zucchi, R. A. (2003). Caracterização morfológica de dez espécies de Trichogramma (Hymenoptera: Trichogrammatidae) registradas na América do Sul. Neotropical Entomology, 32, 597-613. http://dx.doi.org/10.1590/S1519-566X2003000400010

Tironi, P., \& Ciociola, A. I. (1994). Parasitismo natural de ovos de Helicoverpa zea (Boddie, 1850) (Lepidoptera: Noctuidae) por duas espécies de Trichogramma (Hymenoptera: Trichogrammatidae) em culturas de milho em Lavras, MG. Ciência e Prática, 18, 61-67.

Thomazini, M. J. (2001). Insetos associados à cultura da soja no estado do Acre, Brasil. Acta Amazônica, 31, 673-681.

Venzon, M., Ferreira, J. A. M., \& Ripposati, J. G. (2000). Parasitism of stink bug eggs (Hemíptera: Pentatomidae) of soybean fields in the Triangulo Mineiro. Revista de Biologia tropical, 47, 1007-1013.

Zago, H. B., Barros, R., Torres, J. B., \& Pratissoli, D. (2010). Distribuição de ovos de Plutella xylostella (L.) (Lepidoptera: Plutellidae) e o parasitismo por Trichogramma pretiosum Riley (Hymenoptera: $\begin{array}{lllll}\text { Trichogrammatidae). } & \text { Neotropical } & \text { Entomology, } & 39, & \text { 241-247. }\end{array}$ http://dx.doi.org/10.1590/S1519-566X2010000200015

Zucchi, O. L. A. D., Parra, J. R. P., Silveira Neto, S., \& Zucchi, R. A. (1989). Desenvolvimento de um modelo determinístico comportamental para simular o controle de Heliothis virescens (Fabr., 1781) através de Trichogramma spp. Anais da Sociedade Entomológica do Brasil, 2, 357-365.

Zucchi, R. A., \& Monteiro, R. C. (1997). O gênero Trichogramma na América do Sul. In J. R. P. Parra, R. A. Zucchi (Eds.). Trichogramma e o controle biológico aplicado (Cap. 3, pp. 41-66). Piracicaba: FEALQ.

\section{Copyrights}

Copyright for this article is retained by the author(s), with first publication rights granted to the journal.

This is an open-access article distributed under the terms and conditions of the Creative Commons Attribution license (http://creativecommons.org/licenses/by/3.0/). 